\title{
THE EFFECT OF E-SERVICESCAPE DIMENSIONS ON REPURCHASE INTENTION WITH TRUST AS AN INTERVENING VARIABLE
}

\author{
Rahayu Aprianti ${ }^{\star 1}$, Indira Rachmawati ${ }^{2}$ \\ Universitas Telkom, Indonesia*12 \\ rahayu.aprianti98@gmail.com*1, indira.rach@gmail.com²
}

\begin{abstract}
This research to determine how much influence the e-servicescape dimension has on repurchase intention through trust as an intervening variable. The object of this study is the food-delivery service on mobile applications, Grab Food. The population used in this study were users of Grab Food services in Indonesia with a sample of 400 respondents who had purchased products through Grab Food in Indonesia obtained using purposive sampling techniques. Samples were obtained from distributing online questionnaires via Google Form. The independent variables used in the study are the eservicescape dimensions, namely: aesthetic appeal, layout and functionality, and financial security. The dependent variable used in this study is repurchase intention and trust as intervening variables. The data analysis technique used in this research is Structural Equation Modeling with Covariance Based Structural Equation Modeling (CBSEM). Based on the results of research that has been done, E-servicescape has a positive and significant effect on repurchase intention through trust variables.
\end{abstract}

Keywords: E-Servicescape, Food Delivery Service, Repurchase Intention, Trust

\section{INTRODUCTION}

Internet usage enhances development, this happens because the internet is a collection of computer networks that can connect various sites such as individuals, governments, academics, organizations to commercial. The country of Indonesia is one of the countries that use a lot of the population using the internet. This is proven by a survey conducted by the Indonesian Internet Service Providers Association (APJII), acknowledging that data on internet users in Indonesia in 2019 had reached 171.17 million users or around $64.8 \%$ of the total 264 million users of the Indonesian state (Pratomo, 2019).

Based on the contribution of the use of the internet in Indonesia, the availability of the internet has an impact on businesses in increasing the marketing of products and services widely. This change is a new challenge for business people because interaction with the internet gives birth to a variety of new business models, one of which is the application-based business (Basuki, 2019).

The application-based business
model is considered to bring

opportunities for business people to design marketing strategies and achieve optimal business opportunities, as practiced by Grab companies. The presence of this application brings great benefits to consumers. The types of services offered by Grab are, Grab Bike, Grab Car, Grab Express, Grab Fresh, Grab Financial, Grab Rental and Grab Food, but the services most favored by consumers are Grab Food (Jeko, 2019). This was confirmed by Franedya (2019) who explained that one of the services that are widely used by consumers is the Grab Food Service. This is evidenced by research conducted by Kantar that states Grab Food contributes to reaching $20 \%$ of the company's Gross Merchandise Value which was originally only $5 \%$ and Grab Food is claimed to have better margins than ride-hailing.

Grab Food is an online fooddelivery service platform, this service has competitors such as Go Food, KlikEat, Raja Makan, Foodpanda, and Kulineran, but among these competitors Go Food is considered a strong competitor because it is one of the service providers the biggest online food delivery. Go Food has been chosen by consumers because the services 
provided are easy to use or user friendly and the food or beverage menu offered is more diverse than Grab Food (Naufal, 2019).

Along with the many companies that provide online food-delivery services, there are many ways companies can do to be able to compete optimally to get consumers through eservicescape. An understanding of eservicescape is considered to be a natural progression in taking the quality of physical services and integrated into the online service environment, service improvement by paying attention to the concept of e-servicescape is important to be done by digital technology-based service providers, this can make users feel safe and comfortable when using services through the application and the desire arises to reuse and repurchase through its services in the long term (Oebit \& Sari, 2018). However, in conducting transactions online consumers want to minimize the uncertainties and complexities that occur so that to be effective it needs trust built by consumers, besides the trust factor can affect the intention to repurchase a product or service (Amini \& Akbari, 2014). Based on the description above, a study was conducted to find out the relationship between the dimensions of eservicescape in the Grab Food application to the trust of Grab Food customers and assess the impact on repurchase intention.

E-servicescape is an online virtual space that is felt by site visitors when exploring or receiving company services through a website that is divided into three dimensions, namely aesthetic appeal, layout and functionality, and financial security (Harris \& Goode, 2010). Praptono \& Haryanto (2016) explained that e-servicescape plays an important role in business because potential customers will first observe the website pages before making a transaction.

Trust is the willingness of the company to rely on business partners and depends on some interpersonal and organizational factors that influence trust, such as company competence, integrity, honesty, and goodness (Kotler \& Keller, 2016). According to Wilson and Keni (2018) trust can be defined as the customer's confidence to transact with a company based on the credibility and reliability of that company.

According to Kotler \& Armstrong (2016), repurchase intention is the assessment of individuals to buy back a product or service offered by a company, then recommend the company to other consumers. According to Nurhayati \& Murti (2012), repurchase intention is the desire and actions of consumers to repurchase a product or service, because of the satisfaction received under what is desired from a product or service.

This research refers to the concept of online servicescape from Harris \& Goode (2010) applied to a website and also research conducted by Oebit and Sari (2018) about the concept of eservicescape in an application consisting of three variables, namely: aesthetic appeal, layout and functionality, and financial security, as well as the relationship of the three variables to the trust variable. Furthermore, it examines the relationship between trust as a mediator variable with repurchase intention which refers to the research of Amini \& Akbari (2014). 


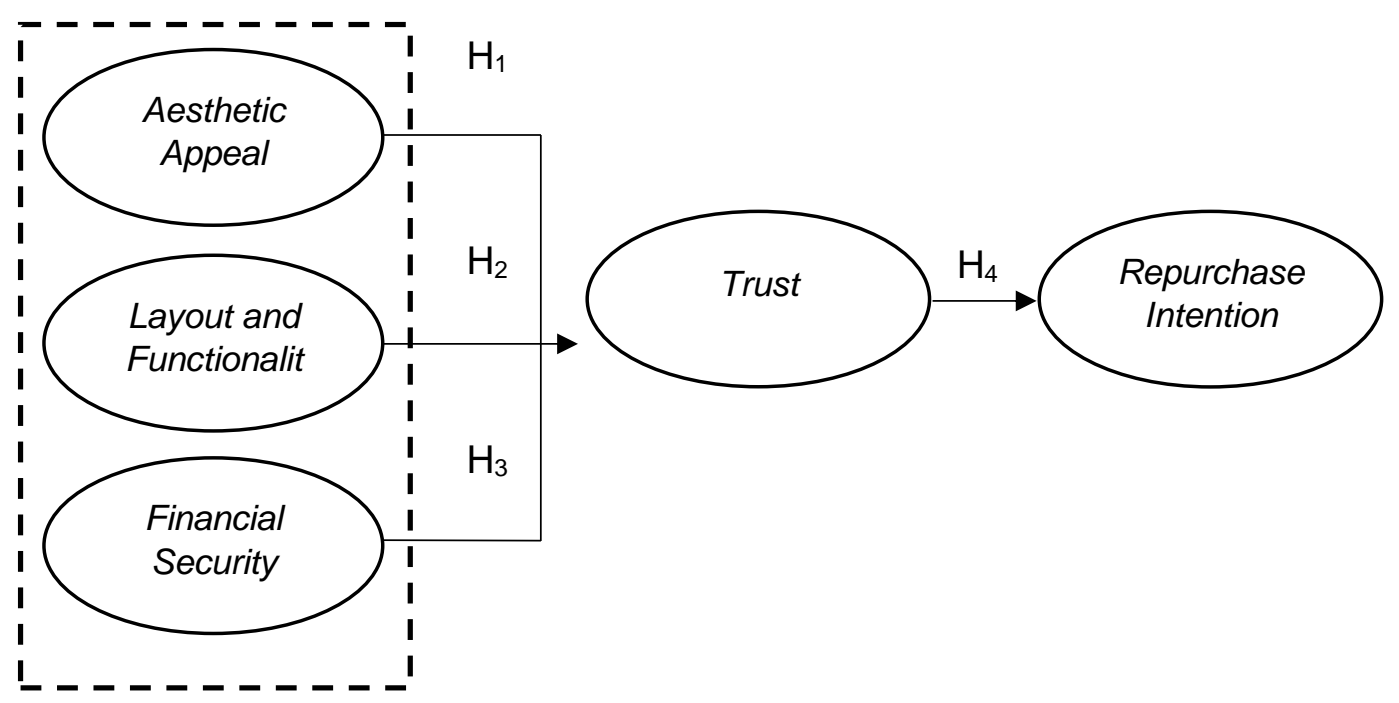

Figure 1. Framework

Source: Oebit \& Sari (2018)

The hypothesis in this research is: $\mathrm{H} 1$ : Aesthetic Appeal has a positive and significant effect on Trust.

H2: Layout and Functionality has a positive and significant effect on Trust. H3: Financial Security has a positive and significant effect on Trust.

$\mathrm{H} 4$ : Trust has a positive and significant effect on Repurchase Intention.

\section{METHODS}

This research uses quantitative research methods with causal objectives. Based on the implementation time, this research is included in the cross-sectional type. This research was conducted in an unregulated situation and the author did not intervene in the data so there was no manipulation in this study. The data source comes from an online questionnaire distributed to individuals so that the unit of analysis in this study is individuals.

The population used in this study are all Grab Food application users in Indonesia who have ordered food and beverage products. The sampling technique used in this study is nonprobability sampling, namely purposive sampling. The number of samples in this study was determined by the Bernoulli formula. The minimum sample calculation in this study was 384 respondents, but the authors rounded off to 400 respondents. This research was conducted in Indonesia with a time and period of research for 4 months, namely October 2019 to February 2020. The object of this study was to Grab Food users in Indonesia.

Data collection in this study used an online questionnaire through Google Form that was distributed via a link to Grab Food users in Indonesia. To ensure the respondents in this study were on target, the authors screened respondents by adding question items at the beginning of the questionnaire.

Data analysis techniques used in this study are Structural Equation Modeling (SEM), path analysis, and Confirmatory Factor Analysis (CFA). This study uses CB-SEM because it is more aimed at explaining the relationships between items in variables and confirming models from pre-existing theories. The software used in this study is LISREL 8.72.

\section{RESULTS AND DISCUSSION}

Based on the results of the questionnaire that was distributed to 400 respondents, the majority of respondents in this study were female, aged 20-24 years, domiciled in Western Indonesia, and had a frequency of buying more than four times a month. 
There are two stages in SEM analysis, namely the measurement model and the structural model. The estimation technique used in this study is maximum likelihood. To test the measurement model, testing the validity and reliability of the indicators used in the study. All indicators in this study have a loading factor value $>0.5$. This means that each manifest variable is declared valid in forming the construct, as shown in Figure 2.

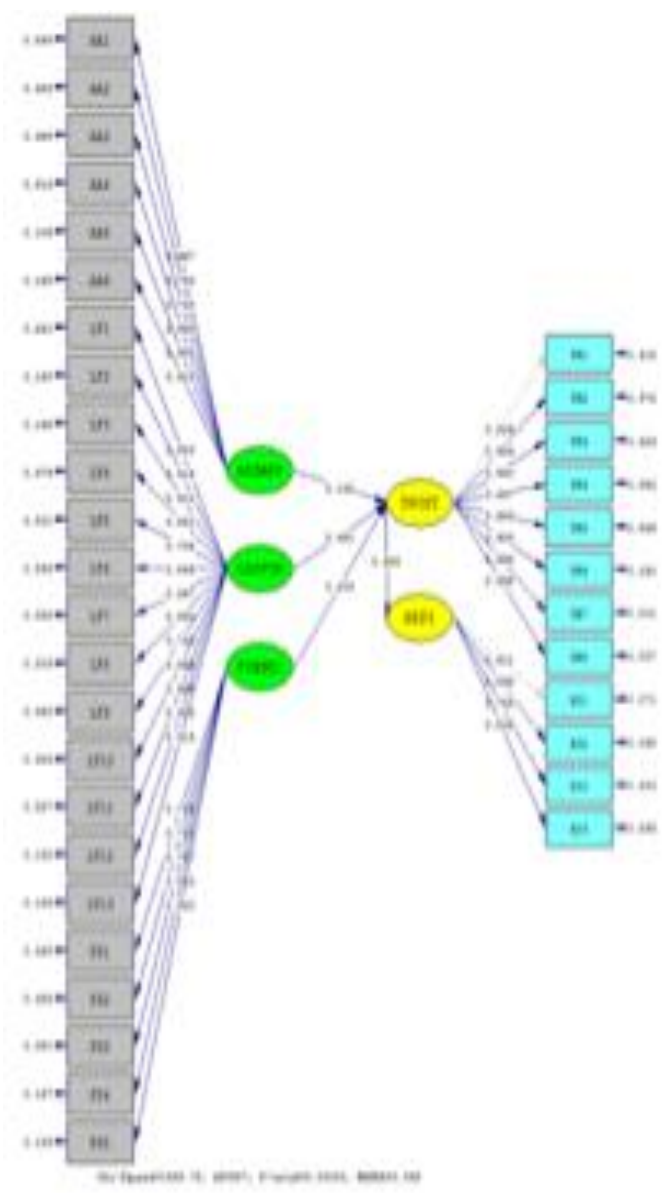

Figure 2. Standardize Loading Factors Source: Processed Data (2020)

Furthermore, for the structural model test, estimates obtained from LISREL are summarized in Table 1. as follows:
Table 1. Recapitulation of Estimated Results

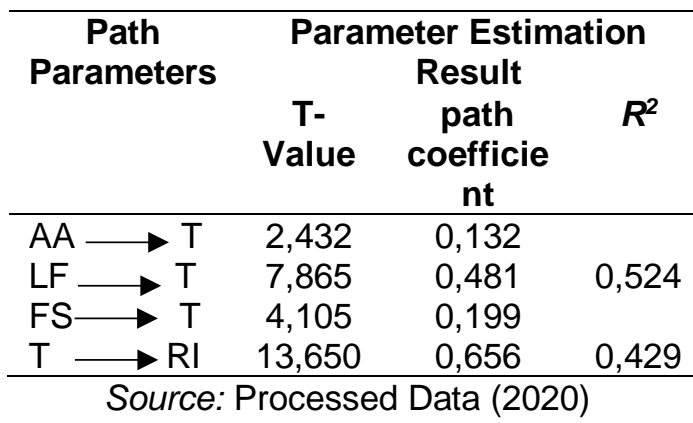

Based on Table 1, Aesthetic appeal has a positive and significant effect on Trust of 0.132 with a t value greater than the critical value of $(|2,432|>1,96)$, Layout and functionality have a positive and significant effect on Trust amounting to 0.481 with a t value greater than the critical value of $(|7,865|>1,96)$, Financial Security functionality have a positive and significant effect on Trust of 0.199 with a value of $t$ greater than the critical value of $(|4,105|>1,96)$, and Trust has a positive and significant effect on Repurchase Intention of 0.656 with a $t$ value greater than the critical value of $(|13,650|>1.96)$. The total effect of the EServicescape dimension on Trust is 0.524 or $52.4 \%$ while the remaining $47.6 \%$ is influenced by other variables not observed in this study. While the total influence of the Trust on Repurchase Intention is 0.429 or $42.9 \%$ and the remaining $57.1 \%$ is influenced by other variables not observed in this study.

Based on these descriptions, as a whole it can be concluded the results of testing the hypothesis in this study in table 2 as follows: 
Table 2. Summary of Hypothesis Test Results

\begin{tabular}{lc}
\hline \multicolumn{1}{c}{ Research Hypothesis } & Conclusion \\
\hline H1 Aesthetic Appeal $\longrightarrow$ & Accepted \\
Trust & \\
H2 Layout and & \\
Functionality & \\
Trust & Accepted \\
H3 Financial Security & \\
Trust & Accepted \\
H4 Trust & \\
Repurchase Intention & Accepted \\
\hline \multicolumn{2}{l}{ Source: Results of the Author $(2020)$}
\end{tabular}

There is nine Goodness of Fit criteria that justify this study, the results of the fittest of this research model are presented in the following table:

Table 3. Goodness of Fit

\begin{tabular}{cccc}
\hline & $\begin{array}{c}\text { The } \\
\text { goodness } \\
\text { of Fit } \\
\text { Index }\end{array}$ & Result & Conclusion \\
\hline 1. & $\begin{array}{c}\text { Chi- } \\
\text { 2quare }\end{array}$ & 1595,75 & Poor Fit \\
2. & RMSEA & 0,066 & Good Fit \\
3. & NFI & 0,976 & Good Fit \\
4. & NNFI & 0,984 & Good Fit \\
5. & IFI & 0,986 & Good Fit \\
6. & RFI & 0,974 & Good Fit \\
7. & GFI & 0,818 & Marginal Fit \\
8. & AGFI & 0,794 & Marginal Fit \\
9. & CFI & 0.986 & Good Fit \\
\hline \multicolumn{3}{c}{ Source: Latan (2012) \& Riadi (2018) }
\end{tabular}

Table 3 explains that from the nine model fit criteria, it shows that there is one measure of Goodness of Fit that is not good or poor fit, that is, on chi-square which has a p-value below the cut-off value, the results of this research have a chi-square value of 1595.75 and the $p$ value of 0.0 or less than the cut-off value $(\geq 0.05)$.

There are six model fit criteria that show the results of a good fit or good fit, namely at RMSEA, NFI, NNFI, IFI, RFI, and CFI. The RMSEA value in this study is 0.066 or smaller than the cut-off value of 0.08 which means a good fit. The NFI value in this study is 0.976 or greater than the cut-off value of $\geq 0.90$, it can be concluded that good fit. The NNFI value in this study is 0.984 or greater than the cut-off value of $\geq 0.90$, it can be concluded that good fit. The IFI value in this study is 0.986 or greater than the cut-off value of $\geq 0.90$ which means a good fit. The RFI value in this study is 0.974 or greater than the cut-off value of $\geq 0.90$ which means a good fit. CFI value in this study was 0.986 or greater than the cut-off value of $\geq 0.90$, it can be concluded that good fit.

The two models fit criteria that show the model fit results that are still acceptable or marginal fit are GFI and AGFI. The GFI value in this study is 0.818 and the AGFI value in this study is 0.794 while the cut-off value is $\geq 0.90$, it can be concluded that GFI and AGFI have a marginal fit meaning.

\section{CONCLUSION}

The conclusion of the study entitled "The Effect of E-Servicescape Dimensions on Repurchase Intention with Trust as Intervening Variables (Studies on Grab Food Users in Indonesia)" all dimensions of EServicescape positively and significantly affect consumer confidence. This means that the better the E-Servicescape of an application will increase consumer confidence. Consumer trust positively and significantly influences repurchase intentions by consumers when using the application. This means that all the high levels of consumer confidence in using services through applications (in the context of this research, namely food delivery service Grab Food) will further increase consumer repurchase intentions.

The results of this study can be used by companies and application developers to create better strategies in shaping consumer confidence, thereby giving rise to an intention to repurchase the services offered by the company. Consumers intend to repurchase one of them because there is a sense of trust after using and evaluating the application environment used. This needs to be considered by application- 
based service companies to increase the dimensions of E-Servicescape of their applications so that consumer confidence increases, especially in the aspect of E-Servicescape that is known to have the least path coefficient value on consumer confidence, namely the appeal of Aesthetic Appeal.

Aesthetic Appeal aspects or aesthetic appeal can increase consumer confidence in using an application, because the application design is creative and innovative and how companies display their products attractively, can make consumers feel happy and trust when using the application. These things need to be increased again by the company because there are still shortages. Likewise from the layout and functionality aspects of an application that also affects consumer trust, companies can maintain or even improve this aspect by developing each subdimension of Layout and Functionality, for example, to increase customization or personalization subdimensions, artificial intelligence can be added. ) such as machine learning to study consumer habits to create applications that are more personalized and following consumer desires.

\section{REFERENCES}

Amini, M., \& Akbari, H. (2014). Studying Effect of Site Quality on Online Repurchase Intention Through Satisfaction, Trust, and Commitment of Customer. Indian Journal of Fundamental and Applied Life Sciences, 4(4), 28392849.

https://pdfs.semanticscholar.org/8 cc9/df9fb2d4b773416c1c4b69d74 46e65dacefd.pdf.

Basuki, D. (2019). Pikirkan Kembali Model Bisnis Anda. https://www.indonesiana.id/read/6 8231/pikirkan-kembali-modelbisnis-anda.

Franedya, R. (2019). Alasan di Balik Grab Jadikan Grab Food Mesin Pencetak

Cuan. https://www.cnbcindonesia.com/t ech/20190918054520-37-

100200/alasan-di-balik-grab-

jadikan-grabfood-mesinpencetak-cuan

Harris, L. C., \& Goode, M. M. H. (2010). Online servicescapes, trust, and purchase intentions. Journal of Services Marketing, 24(3), 230238.

https://www.emerald.com/insight/ content/doi/10.1108/0887604101 1040631/full/html.

Jeko. (2019). Rajai Asia Tenggara, Ini 8 Negara Grab Beroperasi hingga Jadi Decacorn. https://www.liputan6.com/tekno/re ad/3906771/rajai-asia-tenggaraini-8-negara-grab-beroperasihingga-jadi-decacorn.

Kotler, P., \& Armstrong, G. (2016). Principles of Marketing Sixteenth Edition: Global Edition. England: Pearson Education Limited.

Kotler, P., \& Keller, K. L. (2016). Marketing Management 15 Edition: Global Edition. England: Pearson Education Limited.

Latan, H. (2012). Structural Equation Modeling Konsep dan Aplikasi Menggunakan Program LISREL 8.80. Bandung: Alfabeta.

Naufal, I. (2019). Milenial Lebih Pilih GoFood Ketimbang Grab Food. https://inilah.com/ototekno/25355 93/milenial-lebih-pilih-go-foodketimbang-grabfood.

Nurhayati., \& Murti, W. W. (2012). Analisis Faktor-Faktor yang Mempengaruhi Minat Beli Ulang Masyarakat terhadap Produk Handphone. Value Added, 8(2), 47-62.

https://jurnal.unimus.ac.id/index.p $\mathrm{hp} /$ vadded/article/view/717.

Oebit, Z., \& Sari, P. K. (2018). Pengaruh E-Servicescape terhadap Trust dan Dampaknya pada Repruchase Intention: Studi Kasus GO-FOOD. Jurnal Sistem Informasi, 14(2), 43-50. https://jsi.cs.ui.ac.id/index.php/jsi/ article/view/698/387. 
Praptono, L. H., \& Haryanto. (2016). Purchase Intention: Apakah Tampilan Website Berpengaruh?. Jurnal Manajemen dan Kewirausahaan, 14(2), 101-111. https://jurnal.uns.ac.id/fokusmanajerial/article/view/8440.

Pratomo, Y. (2019). APJII: Jumlah Pengguna Internet di Indonesia Tembus 171 Juta Jiwa. https://tekno.kompas.com/read/20 19/05/16/03260037/apjii-jumlahpengguna-internet-di-indonesiatembus-171-juta-jiwa.
Riadi, E. (2018). Statistik SEM Structural Equation Modeling dengan LISREL. Yogyakarta: Andi.

Wilson, N., \& Keni. (2018). Pengaruh Website Design Quality dan Kualitas Jasa terhadap Repurchase Intention: Variabel Trust sebagai Variabel Mediasi. Jurnal Manajemen dan Pemasaran Jasa, 11(2), 291-310. https://media.neliti.com/media/pu blications/274691-pengaruhwebsite-design-quality-dan-kualb18a9509.pdf. 